\title{
Green Digits: Towards an Ecology of IT Thinking
}

Pierre Berthon ${ }^{1,2}$, Philip DesAutels ${ }^{2}$, Brian Donnellan ${ }^{3}$ and Cynthia Clark Williams ${ }^{2}$

${ }^{1}$ Corresponding author

2 Bentley University

${ }^{3}$ National University of Ireland 


\title{
Green Digits: Towards an Ecology of IT Thinking
}

\begin{abstract}
Green IT is a hot topic: to be glib, it has warmed in tandem with the planet. It is seen as a potent tool in the fight against global warming. However, despite the promise of technology to deliver planetary solutions, the employment of IT has been beset by a number of paradoxes. For example the 'paperless office' was buried in paper; the clean world of high tech was built on piles of toxic waste; and educational laptops for the developing countries ended up as second or third netbooks for the wealthy. Sometimes IT has done more to compound problems than create sustainable solutions. However to date the discussion of Green IT has either focused at the level of information technology or at the level of information systems. In this chapter we explore Green IT by focusing on a third, and neglected level information technology: information views, or 'ways of thinking'. We suggest that it is this ignored conceptual level that has, in part, contributed to the paradox of IT. Specifically we differentiate instrumental from emergent thinking about technology, and identify three paradigms of sustainability which suggest very different uses of information technology to achieve the goal of a viable planet.
\end{abstract}




\section{Green Digits: Towards an Ecology of IT Thinking}

"The most thought-provoking thing in our thought-provoking time is that we are still not thinking"

Heidegger

\section{Introduction}

The world faces an ecological crisis: population, pollution and planetary perturbation. Despite years of industry funded propaganda, the scientific evidence for the unsustainable nature of modern living has become overwhelming. As humans, we are faced with a stark choice: change or face the possibility of extinction. There are differing opinions as to the causes of our ecological crisis, but there are many symptoms: on the abiotic front we are faced with rising temperatures, decreased rainfall, desertification, rising sea levels, vast toxic wastelands and acidification of the oceans. On the biotic front we are faced with over population, de-speciation,

extinctions, and decreasing biodiversity in terms of both species and ecosystems. Hart (1997) argues that humans have contributed to the ecological crisis in three ways: population, life-style and technology. Increased human population, living an unsustainable, environmentally destructive lifestyle have drained the earth of resources and flooded it with pollutants. The enabling mechanism for both the increase in population and the increase in affluence has been technology. Technology is the multiplier effect for every human action: and to date our technology has been focused on human needs without thought for the environment. The ecological crisis is forcing us to change our myopic views of both the environment and technology. Indeed the irony is that technology may well be the mechanism for our savior as it has been the instrument of our plight.

To say we are still learning about our relationship with nature is palpable, however what is less obvious is that we are still learning about our relationship with technology. Indeed we have been 
as unconscious in our relationship with technology as we have been in our relationship with nature. We tend to think of both nature and technology as "other": something out there; something separate from us. The difference being that we find the former and create that latter but we treat them both the same: instrumentally. That is we use both technology and nature for our own ends. The ecological crisis has alerted us to the fact that our use of technology is causing us to consume and alter nature in unsustainable ways. While our ecological awareness has increased, our relationship with technology is more ambivalent. Indeed our use of technology for instrumental purposes has been plagued by paradoxes of intent and result.

\section{IT Paradoxes}

Much has written about the information technology paradox (cf. Thatcher and Pingry, 2007) - IT was meant to be the solution to inefficiency, yet in many ways, IT has failed to deliver the productivity gains promised. IT has done more to shift business practices than make industry more efficient. Further, IT has not delivered on its promise of increased leisure and freedom, but has rather blurred the boundaries of personal and work to the extent where many are always working. Now with the emerging climate and energy crisis, IT is once again being touted as a solution: Can it deliver this time? We argue that it can, but will require (1) a deeper understanding of our relationship with technology, and (2) a more thoughtful reflection on what it means to be green: there are many shades of green.

Information systems, that is, the design and implementation of entire systems of storage and retrieval, have promised the world - but more soberly have done more to change it than deliver it. IT, or the software and hardware that enables us to do more, faster; but to what end? Indeed the history of information technology has been beset by paradoxes. A few are summarized below, under the headings of: The promise of efficiency, the promise of cleanliness, the promise of education, the promise of satisfaction and the promise of community.

\section{The Promise of Efficiency}

- The paperless office: Ironically, advances in IT have contributed to a massive explosion of the use of paper and concomitant deforestation (Sellen and Harper, 2001). 
- Energy consumption: It has increased energy efficiency, but also increased overall energy consumption (Thatcher and Pingry, 2007). A recent report suggests that IT installations are one of the highest consumers of energy per unit of space occupied.

- Human labor: The paradox of computers, automation and labor - computers, IT and robots were originally envisaged to reduce work: they were labor saving devices however, this has not been the case. Indeed in some countries automation has increased the hours humans work each week (Jackson, 2008).

- Leisure: Rather than increasing the leisure time of individuals the flexibility that IT enables has blurred the distinction between work and the personal (Rubery et al., 2005).

The Promise of Cleanliness

- Clean technology: Despite the promise of clean technology, the disposal of IT equipment has become a major environmental problem: toxic materials in components have been found to be detrimental to many forms of life - including human (Grossman, 2006).

- Waste: Approximately 93\% of the materials consumed never end up in salable products and an estimated $99 \%$ of the materials in products of used in their manufacture end up as waste within 6 weeks of their sales (Weizsacker et al., 1997). Likewise, most products have been deliberately designed for obsolescence (Slade, 2006), a condition that has existed for decades (Packard, 1960).

The Promise of Education

- Enhanced education: One laptop per child initiative - research suggests that this is detrimental to student learning (Cuban, 2001; Ofer and Pop-Eleches, 2008)

- Sustainable education: IT as a solution of sustainable global education - environmental footprint much greater than traditional methods (Smith, 2004)

- More information - less knowledge. Agnotology. Derived from the Greek root agnosis, it is "the study of culturally constructed ignorance" As information has become more widely available people have become less informed: more information has lead to greater ignorance (Manjoo, 2008)

- Pollution of the mind: internet addition, obsession with violent games, rewiring of the human brain (Rosen, 2008)

- Information and knowledge: Information overload is destroying the ability to focus attention - nuanced thinking is replaced by simplistic black and white thinking Reflection 
and creative thinking is replaced by distraction and bounded and shallow thinking. (Keim, 2009)

The Promise of Satisfaction

- Consumer satisfaction: Information technology promises to deliver both increased firm efficiencies and customer satisfaction (cf. Day, 1991). Yet the paradox is that in recent years, despite accelerated investment in service industries such as banking, both productivity and customer satisfaction have deteriorated (Olazabal, 2002).

- Happiness: Technology offers the promise of a better and easier life yet paradoxically, as the rate of technological change in modern life has increased, happiness and societal health have decreased. Rather than yielding their promise of happiness, the consequences of technology, Toffler's 'Future Shock!" seem to have yielded a negative result, (Toffler 1970, Miringoff et al, 1999)

The Promise of Community

- The paradox of connection: IS has delivered the dream of instant communication between people and groups almost anywhere on the planet: we live in a hyper connected, socially networked world - contact is only a click away. Yet despite this study after study has demonstrated that it is precisely this technology of connection that is resulting in increased isolation. As people spend more and more time in mediated interaction, unmediated interaction is declining, resulting in a potential epidemic of loneliness, depression and concomitant diseases (Sigman, 2009).

The point here is not to present some dystopian, Malthusian picture of technology, but highlight the fact that intention and manifestation are typically as odds; and it is the acknowledgement of this that may be critical if we are to use information systems to help us out of the ecological predicament that that we find ourselves.

In this paper we explore the paradox of IT and IS and the promise of these as one of the solutions to our ecological predicament. We explore Green IT by focusing on a third, neglected level of information systems analysis: Information Views, or 'ways of thinking' about information technology and systems. We suggest that it is this ignored conceptual level that has in part contributed to the IT paradoxes. Specifically we differentiate instrumental vs. emergent thinking 
about technology, and identify three paradigms which suggest very different uses of information technology to achieve the goal of Green IT in the service of sustainability.

\section{Green IT}

Terms such as green computing, Green IT and Green IS have been used loosely and interchangeably in government and industry for some years; all are closely linked to the concept of sustainability. This latter term is generally considered to mean a strategy of meeting the needs of the present without compromising the ability of future generations to meet their own needs (Brundtland, 1987, p. 8). This somewhat ambiguous definition, which privileges society over the environment, conflates fact, intent, and value, and leaves a high degree of latitude for interpretation. Others have tried to operationalize the definition for practical implementation. Marshall and Toffel (2005) identify four such frameworks of sustainability: the triple bottom line (Elkington, 1998), the natural step (Nattrass and Altomare, 1999), the ecological footprint (Wackernagel and Rees, 1996) and the sustainable emissions and resource usage (Graedel and Klee, 2002). These are summarized in Table 1.

Table 1: Sustainability Frameworks

\begin{tabular}{|c|c|c|c|}
\hline The Triple Bottom Line & The Natural Step. & The Ecological Footprint. & $\begin{array}{l}\text { Sustainable Emissions and } \\
\text { Resource Usage. }\end{array}$ \\
\hline $\begin{array}{l}\text { Organizations pursuing } \\
\text { sustainability make decisions } \\
\text { based on three criteria: } \\
\text { economic returns: } \\
\text { environmental protection and } \\
\text { social equity. These three } \\
\text { elements can be combined: } \\
\text { eco-efficiency, balances } \\
\text { economic and environmental } \\
\text { goals; fair trade balances } \\
\text { economic activities with social } \\
\text { justice; and environmental } \\
\text { justice balances social equity } \\
\text { with environmental protection }\end{array}$ & $\begin{array}{l}\text { A sustainable society is one in } \\
\text { which human needs are met } \\
\text { worldwide meets, but that } \\
\text { nature is not subject to } \\
\text { systematically increasing: } \\
\text { concentrations of substances } \\
\text { extracted from the earth's crust; } \\
\text { concentrations of substances } \\
\text { produced by society; and } \\
\text { degradation by physical means }\end{array}$ & $\begin{array}{l}\text { Sustainability is calculated by } \\
\text { comparing the environmental } \\
\text { impact of specific actions to the } \\
\text { limitations of the earth's } \\
\text { natural resources and } \\
\text { ecosystem functionality. The } \\
\text { ratio of "how many earths" } \\
\text { would be required to provide } \\
\text { enough biologically productive } \\
\text { land area to maintain the flows } \\
\text { of resources and wastes, if } \\
\text { everyone lived like a specific } \\
\text { person or group of people. }\end{array}$ & $\begin{array}{l}\text { A sustainable rate of resource } \\
\text { use can be determined by: (i) } \\
\text { calculate the available supply } \\
\text { of virgin materials (mass); (ii) } \\
\text { allocate consumption of this } \\
\text { supply over a specific time } \\
\text { scale and among the global } \\
\text { population (mass per person } \\
\text { per year); (iii) account for } \\
\text { recycling and for existing } \\
\text { stockpiles and then update the } \\
\text { allocated consumption rate; and } \\
\text { (iv) consider this rate to be the } \\
\text { maximum sustainable } \\
\text { consumption rate and compare } \\
\text { it to the current usage rate. }\end{array}$ \\
\hline
\end{tabular}




\section{From Information Technology to Information Views}

Watson (2008) differentiates Green information technology from Green information systems. The former focuses primarily on the matter and energy embodiment of information technology. It is concerned with issues such as efficiency, recycling of materials, reduction or elimination of toxic compounds in manufacturing, renewable energy etc. In contrast Green IS focuses on the design and implementation of information systems - the linking together of components into purposeful organizations. Here the focus is on systemic initiatives to manage the transport of matter, energy and information for optimum efficiency and effectiveness. Examples include systems to manage the energy consumption of an airline fleet, systems to manage traffic flow, systems to optimize information streams over the internet etc. However the question must be asked: how do we decide the purpose of an information system? What does it mean to produce an efficient and effective technology or system? We propose that what has been lacking in the debate around Green IT, is not the technology or the systems, by the ways of thinking that underpins each. The paradoxes outlined above all too clearly show that despite the best intentions of designers and managers, information technology has had a poor ecological track record. Why? Perhaps because of our naive relationship to technology and our simplistic understanding of what it means to be sustainable.

Green information views (Green IV) has two important elements - how we think about technology and how we think about the environment. We discuss each in turn.

\section{Re-Viewing Technology}

Heidegger (1983) notes that the common view of technology is twofold: first technology is instrumental - i.e. that it is a means to an end; a means of getting something done. Second, it is anthropological - i.e. the product of human activity; simply humans create technology. Whilst this view is undoubtedly correct, it is also partial and misleading. Technology, Heidegger (1983) points out, stems from the Greek $\tau \dot{\chi} \chi v \eta$, techne. There are two aspects to this term. First, techne is more than the Greek for the activities and skills of the craftsperson, it is also for the art of the mind; techne is a 'bringing forth', a 'revealing'; it is a form of poiesis, a poetic creation. Second, from early Greek times, the word techne is linked with episteme. Both words are essential parts 
of knowing. Aristotle unites and differentiates thus: episteme and techne - the "what" and "how" of revelation. Heidegger's etymological review of the word technology suggests a very different meaning from the popular, instrumental view of technology as a means to an end: technology is also a mode of revelation. Here Heidegger employs the Greek word $\dot{\alpha} \lambda \dot{\eta} \theta \varepsilon 1 \alpha$, aletheia which literally means "unveiling" or "revealing" and is also the Greek word for "truth." Thus technology is a mode of aletheia, an act of revelation, a process of bringing forth. The compass brings forth a world of magnetic fields; just as the chronograph reveals a world of abstract time.

Once brought forth Heidegger argues that technology becomes a way of seeing: in this context he uses the word gestell, best translated as enframing. Technology becomes a frame of mind, a way of viewing the world: technology becomes a way of seeing. Thus to the stem cell researcher, embryo's become a resource for harvest, to the recycler, trash becomes gold. Technology has both a physical and a conceptual dimension - and it the conceptual dimension of enframing which Heidegger sees as the essence of technology.

To the dominant views of technology as instrumental and anthropologic, we might add the views of technology as aletheia and gestell - technology as revelation and enframing (cf. Berthon et al, 2005). Technology can, therefore, be seen as both emergent and anthropoetic - it creates new ends and shapes the humans that created it - for the essence of technology is not the physical, it is the conceptual. Technology is a frame of mind that shapes both the viewer and the viewed, the actor and the acted. Our technology empowers and possesses us.

Conventionally, technology is seen as a neutral object, the product of people and a tool to enable them to achieve specified ends. To this we can now add, technology as an active subject, a shaper of people and a revealer of new worlds. These four modes of technology can be mapped by two axes. Technology can either be seen as a passive or neutral object or, an active subject or force; and technology is always viewed in relation to the people who created it and to the wider environment or world. This is summarized in Figure 1 below. 
Figure 1: Four Views of Technology

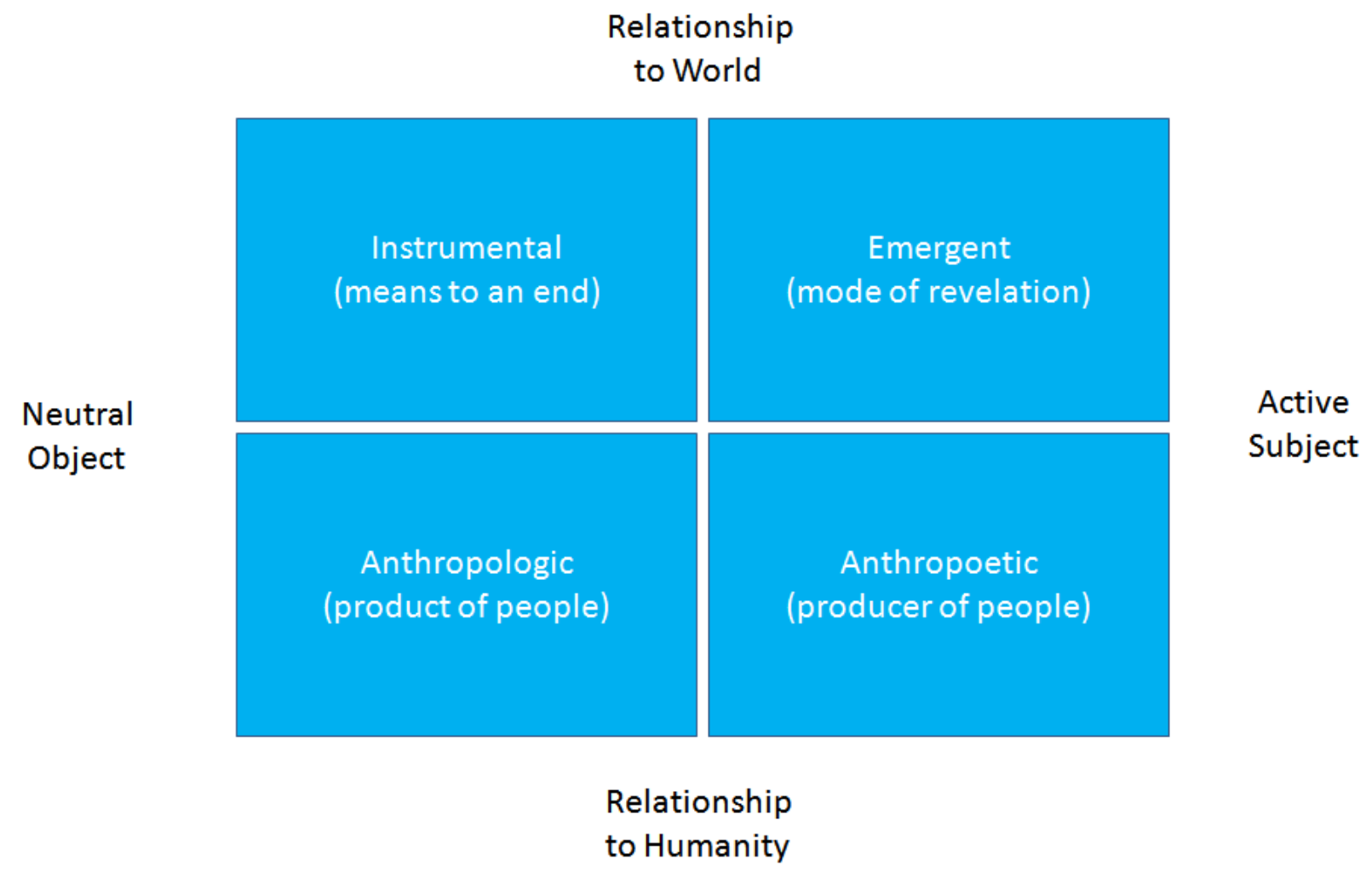

\section{Re-Viewing the Environment}

The relationship between the environment and technology is confounded. In the traditional view, technology is a neutral object produced by people as a means to an end, nature a resource to be exploited. From the perspective, nature is subjugated as a resource which technology can unlock, transform and store for future use as needed (Heidegger, 1977). Technology applied in this way to transform and leverage nature to our own ends does not remain merely a neutral object, but rather becomes an active subject in shaping our view of nature and of technology itself. Through this shifting of views, technology has become more than a tool to transform; it has become a means to reveal our impact on the environment and it has become a producer of successive generations of people, who are more attuned to the environment and our technological impact on it. As technology has moved from a neutral, passive state to an active participatory state, our paradigm of interaction with nature has also shifted drastically. 
The world's market economy encompasses approximately half of the world population, with one billion people in developed nations and two billion in emerging ones (Hart 1997). In emerging nations, technology is used naively as the engine of growth to enable rapid industrialization (and its associated urbanization) and through this industrialization there is movement towards a more developed state. In much the same way as their developmental predecessors, industrial cultures see nature as an inexhaustible resource to be exploited at all costs to increase the standard of living to that of the 'developed' world. Thus, they consume nature regardless of the cost or impact, focusing solely on growth. Those in the poorest countries tend to misuse natural resources often just to survive (Lawrence et al., 2005). Information technology, much in the same light as industrial technology, is seen merely as a tool for growth, a means to achieve the end goal of development or survival.

\section{Questioning the industrial model: the Efficiency Solution}

The industrial model of treating the earth as a resource to be exploited emerged from the enlightenment and the rise of modern science; these "objectified" the natural world in a hitherto radical way. Human kind was set apart and above nature- which was seen as needing to be subjugated to the will of man [sic.]. The exploitation of the natural world proceeded unquestioned in mainstream Western culture until the 1960's when the effects of unbridled harvesting of resources and unrestrained sowing of pollutants became manifest to all but the most myopic denizens (Carson, 1964). Thus, the industrial model gave way to the postindustrial model.

While the ecological impact of the world's emerging economies is evident (deforestation, desertification, mass-urbanization), it is the ecological footprint of the developed world's postindustrial consumer cultures which imparts the predominant planetary impact. In these cultures, while the importance of nature is evident, society and nature are separate. It is the responsibility of society to manage and exploit nature, but to do so responsibly. The realization of the finality of nature has shifted the human-nature relationship to one of stewardship in order to maintain the status quo of life and the environment. Technology holds no more than a neutral role in achieving this goal. The predominant mechanism employed is relentless technocratic efficiency - 
doing more with less, reducing and reusing waste, and minimizing the impact that technology has on nature. Information technology is viewed as an end unto itself and faces the same demands for efficiency that all other technology faces.

\section{Questioning the efficiency solution: the Simplify Model}

Despite the fact that the efficiency model dominates much of current thinking (see Forester report, 2009 for IT and Hawken et al., 1999 for industry), its efficacy is coming under increasing scrutiny. For example Price (2008) starts with an interesting question: is modern efficiency inefficient - does its constant quest to pare down "extraneous" elements in fact make life unsustainable - literally, compromising the ability of future generations to meet their own needs? The issue is that efficiency is typically anthropocentrically defined and over too short a time period. Efficiency for whom and over what time period is seldom asked on the planetary level. The questioning of the efficiency, or management paradigm and the concomitant questioning of the Enlightenment legacy of viewing humans separate and above their environment has lead to radical rethinking.

Out of this arose the deep ecology movement which sees humans as fundamentally and indeed spiritually a product of the earth. Its proponents champion a return to more natural ways of living, reducing our dependence on high tech solutions in favor of simple, appropriate technology and a more harmonious and spiritual way of life. The Amish might be a templar for this model. This counterculture has developed across both emerging and developed economies. This romantic desire to return to nature produces a paradoxical relationship with technology. Technology is treated with distrust and it is seen as the primary cause of society's ecological and social problems (pollution, globalization, conflict, poverty) but it also serves as an enabling tool

of the movement. Information technology is applied to higher purposes to enable the goals of the movement.

\section{Questioning the simplification solution: the Transformation Model}

Despite the neutral (or ambivalent) role that technology has taken in the paradigms described thus far, the anthropoetic impact of technology on society has resulted in the emergence of a fourth wave or way of green that is itself a product of technology. It both rejects the efficiency 
model as misguided, and the back to nature and simply untenable. It is epitomized in movements such as Viridian Design (cf. Steffen, 2006). The perspective here is that what we think of as the "natural" world is a myth; for there is not drop of water, a grain of soil, or a molecule of air that is unaltered by humanity. As Sterling of Viridian Design argues "'Nature" is over. The twentieth century did it in. There's not a liter of seawater anywhere without its share of PCB and DDT. An altered climate will reshuffle the ecological deck for every creature that breathes. You can't escape industrialism and hide from the sky. It's over." (quoted in Roberston, 2008).

This movement embraces that fact that humans are an intrinsic part of nature, but inverts the relationship arguing that nature is now fundamentally "human". Nature thus transformed itself into a product of humanity rather than an entity unto itself. To them, technology is no longer a tool to be leveraged, but rather a means to achieving a post-human cybernetic existence. Information technology is fundamental to this culture and serves a higher purpose, enabling the transformation of both society and the planet.

Each of the four paradigms of human-nature interaction presented here - Exploitative, Technocratic, Romantic and Transformative, is summarized below in table 2. The first two of these present a view of technology as neutral object while in the latter two, technology is an active subject. In the last of these paradigms, Transformative, the impact of technology on the culture is so profound that the very frame of reference for the culture has been shifted. 
Table 2: Paradigms of Human-Nature Interaction

\begin{tabular}{|c|c|c|c|c|}
\hline & $\begin{array}{c}\text { Naive } \\
\text { Exploitative }\end{array}$ & $\begin{array}{c}\text { Efficiency } \\
\text { Technocratic }\end{array}$ & $\begin{array}{l}\text { Simplify } \\
\text { Romantic }\end{array}$ & $\begin{array}{c}\text { Evolve } \\
\text { Transformative }\end{array}$ \\
\hline Strategy & $\begin{array}{l}\text { EXPLOIT } \\
\text { Exploit nature }\end{array}$ & $\begin{array}{l}\text { MANAGE } \\
\text { Preserve nature }\end{array}$ & $\begin{array}{l}\text { RETURN } \\
\text { Return to nature }\end{array}$ & $\begin{array}{l}\text { TRANSFORM } \\
\text { Transform nature }\end{array}$ \\
\hline $\begin{array}{l}\text { Culture } \\
\text { Primary goal }\end{array}$ & $\begin{array}{l}\text { Industrial culture } \\
\text { Growth - at all costs } \\
\text { Increase standard of } \\
\text { living - regardless of } \\
\text { costs }\end{array}$ & $\begin{array}{l}\text { Consumer culture } \\
\text { Maintain the status } \\
\text { quo: standard of } \\
\text { living whilst } \\
\text { minimizing impact }\end{array}$ & $\begin{array}{l}\text { Counter culture } \\
\text { Devolve } \\
\text { Return to a simpler } \\
\text { way of living, }\end{array}$ & $\begin{array}{l}\text { Cyber-culture } \\
\text { Evolve; create new } \\
\text { world }\end{array}$ \\
\hline Examples & $\begin{array}{l}\text { Industrial } \\
\text { Industrial countries } \\
\text { such as China, India } \\
\text { etc. }\end{array}$ & $\begin{array}{l}\text { Post-Industrial } \\
\text { Europe; emerging } \\
\text { paradigm in Western } \\
\text { business today }\end{array}$ & $\begin{array}{l}\text { Deep Ecology } \\
\text { Arne Naess, Gandhi, } \\
\text { E.F. Schumacher's } \\
\text { Small is Beautiful and } \\
\text { Meadows Limits to } \\
\text { Growth Honore's In } \\
\text { Praise of Slow }\end{array}$ & $\begin{array}{l}\text { Bright Green Bruce } \\
\text { Stirling } \\
\text { Viridian Green etc. }\end{array}$ \\
\hline $\begin{array}{l}\text { Relationship } \\
\text { with nature }\end{array}$ & $\begin{array}{l}\text { Separate } \\
\text { Nature is seen an } \\
\text { inexhaustible } \\
\text { resource to exploit }\end{array}$ & $\begin{array}{l}\text { Separate } \\
\text { Nature is a finite } \\
\text { resource to manage; } \\
\text { humans as stewards } \\
\text { of the natural world }\end{array}$ & $\begin{array}{l}\text { Part } \\
\text { We are a product of } \\
\text { narture, but have lost } \\
\text { touch with it - we } \\
\text { need to return } \\
\text { Stresses our deep } \\
\text { spiritual, relationship } \\
\text { with nature } \\
\text { Return to Eden } \\
\end{array}$ & $\begin{array}{l}\text { Part } \\
\text { "Nature is over" - } \\
\text { nature is a product of } \\
\text { humanity; Idealistic } \\
\text { Creative, } \\
\text { Entrepreneurial }\end{array}$ \\
\hline $\begin{array}{l}\text { Relationship } \\
\text { with } \\
\text { technology }\end{array}$ & $\begin{array}{l}\text { Naive } \\
\text { Technology seen as } \\
\text { the unproblematic } \\
\text { engine of growth }\end{array}$ & $\begin{array}{l}\text { Neutral } \\
\text { Technology seen as } \\
\text { neutral. Focus on } \\
\text { efficiency - } \\
\text { minimizing the } \\
\text { impact of technology }\end{array}$ & $\begin{array}{l}\text { Ambivalent } \\
\text { Ambivalence, even } \\
\text { mistrust of } \\
\text { technology } \\
\text { Technology is seen as } \\
\text { a primary cause of the } \\
\text { problem }\end{array}$ & $\begin{array}{l}\text { Utopian } \\
\text { Belief in the power of } \\
\text { technology to } \\
\text { transform, post } \\
\text { human }\end{array}$ \\
\hline View of IT & $\begin{array}{l}\text { Internalist } \\
\text { Bigger, more } \\
\text { powerful } \\
\text { IT an end in itself }\end{array}$ & $\begin{array}{l}\text { Internalist } \\
\text { More efficient } \\
\text { Do more with less } \\
\text { IT an end in itself }\end{array}$ & $\begin{array}{l}\text { Telos } \\
\text { Do less with less - } \\
\text { de-complexify } \\
\text { IT used for a higher } \\
\text { purpose }\end{array}$ & $\begin{array}{l}\text { Telos } \\
\text { Use IT to transform } \\
\text { ourselves and the } \\
\text { planet } \\
\text { IT used for a higher } \\
\text { purpose }\end{array}$ \\
\hline
\end{tabular}




\section{Conclusion}

At the start of this chapter we argued for a third level of IT: to information technology and information systems we need to add an integrating framework of information views - or ways of thinking about technology and systems. We suggest that this new level is particularly important as we contemplate technological solutions to the problem of global warming and planetary change, as IT solutions have in the past been characterized by an etiology of opposite effects. For local problems this may have been overlooked, but in an increasingly strongly interlinked and critically interdependent world there are no local problems.

Drawing on the work of Heidegger we uncover two underappreciated aspects of technology. To the mainstream views of technology as a product of people, created and employed for instrumental ends, we must add a complimentary view: technology as the producer of people and as an emergent, evolving entity in and of itself. For this view we realize that technology cannot be confined to the instrumental - it will always escape our control and change us and how we think of ourselves and our environment in the process.

Turning to the environment, we see that our position towards nature has remarkable parallels with our stance towards technology. Nature has been used instrumentally - as a resource to be exploited. Even humanities' genesis, has until recently been thought of as somehow apart from nature (e.g. Rosenstand, 1994). Ironically, it has been technology that has changed our relationship with nature: technology has revealed our dependence upon our environment through our instrumental use of the environment. This re-faming of our view of nature has produced a variety of different perspectives on sustainability. Each offers us a very different vision of sustainability and the role of Green IT.

The Technocratic solution presents a paradigm of thought focused on efficiency: doing more with less. This level, we argue, is where the bulk of Green IT thinking is at present, and will be critical element to any ongoing strategy. It recognizes the finite nature of resources and the 
importance of getting the maximum out of a given resource; however, in and of itself the Technocratic perspective is incomplete. The Romantic solution recasts the question of our relationship with the environment as a "losing touch" with our natural being. This "fall" is no felix culpa but rather a tragedy of a spiritual dimension. Indeed it is this insight that can help inform Green IT: technology and nature are more than value imbued - they are fundamental aspects of ourselves: nature and technology are the mirrors in which we discover ourselves: at the moment what we see is not pretty. Finally, the Transformative solution offers us the compelling vision of a mutual evolution; it flips the Romantic perspective of 'we are children of nature' to 'nature is now our product'; it stresses radical innovation and entrepreneurial solutions - rather than step back and let nature 'heal' itself, it argues for new forms of nature and humanity.

We argue that Green IV needs to integrate insights from each of these paradigms. From the naïve industrial perspective we take the pragmatic instrumental perspective that humanity will always "use" nature to some extent, and, to some degree, all societies must. Moreover, we need the Romantic to balance the Transformative: least hubris becomes our nemesis. Indeed the emergent aspect of technology should lead us to value what the ancient Greeks termed sophrosyne, selfrestraint, through a reflexive awareness of self-limitations; clearly our ability to predict the future is severely compromised.

So in conclusion, what can we learn from Green IV? First, we cannot treat technology in the way we have nature - instrumentally. Technology manifestly has emergent properties in exactly the same way nature has. Second, any technological solution to manage nature will escape our intentions. Third, every technological solution to manage nature will transform us - radically. Fourth, rather than try to control nature and technology we must build flexibility into our responses to its emergence - and ours. Fifth, rather than try to limit technological repercussions we need to instill values into it; just as nature is now instilling values into us - this is particularly pressing as machines reach and exceed humans. Finally, our future may be more determined by our ecological mindsets than our ecological footprints. 


\section{References}

Berthon, P., Hulbert, J. and Pitt, L. (2005) "Consuming Technology: Why Marketers Get It Wrong." California Management Review, 48 (1): 110 - 128.

Braungart, Michael and William McDonough (2008) Cradle to Cradle: Remaking the Way we Make Things. London: Jonathan Cape

Brundtland, G. H. (1987). Our Common Future: Report of the World Commission on Environment and Development. Oxford: Oxford University Press.

Cuban, L. (2001). Oversold and underused: computers in the classroom. Cambridge, Mass.: Harvard University Press.

Elkington, J. (1998) Cannibals with Forks: The Triple Bottom Line of 21st Century; New Society Publishers: Gabriola Island, BC.

Graedel, T. E.; Klee, R. J. (2002) Getting serious about sustainability. Environmental Science and Technology, 36, 523-529.

Grossman, Elizabeth, (2006) High Tech Trash: Digital Devices, Hidden Toxics, and Human Health. Shearwater.

Hart, S. L. (1997). Beyond greening: Strategies for a sustainable world. Harvard Business Review, 75(1), 66-76.

Hart, S. L. (1997). Beyond Greening: Strategies for a Sustainable World. Harvard Business Review, 75(1), 66-77.

Hawken, P., Lovins, A. B., \& Lovins, L. H. (1999). Natural capitalism : creating the next industrial revolution. Boston: Little, Brown and Co.

Hayes, Brian (2009) Automation on the job. American Scientist, 97 (1): 34-40.

Heidegger, M. (1977). The question concerning technology, and other essays. New York: Harper \& Row.

Jackson, Maggie (2008) Distracted: The Erosion of Attention and the Coming Dark Age. Prometheus Books: New York.

Laitner, J. and Ehrhardt-Martinez K., (2008) "Information and Communication Technologies: The Power of Productivity - How ICT Sectors are Driving Gains in Energy Productivity", Report No. E081, American Council for an Energy Efficient Economy, February. 
Lawrence, A. T. Weber, J.E. Post, J. (2005). Business \& Society: Stakeholders, Ethics and Public Policy. New York: McGraw Hill.

Malamud, Ofer and Cristian Pop-Eleches (2008) The Effect of Computer Use on Child Outcomes. University of Chicago, Working Paper: wp.08.12.

Manjoo, Farhad (2008) True Enough: Learning to Live in a Post-Fact Society. Wiley.

Marshall, J.D. \& Toffel, M.W. (2005) Framing the Elusive Concept of Sustainability: A

Sustainability Hierarchy. Environmental \& Scientific Technology 39 (3): 673-682.

McDonough, William and Michael Braungart (2002) Cradle to Cradle: Remaking the Way We Make Things. North Point Press.

Miringoff, M. L., Miringoff, M.-L., \& Opdycke, S. (1999). The social health of the nation : how America is really doing. New York: Oxford University Press.

Nattrass, B. and Altomare, M. (1999) The Natural Step for Business: Wealth, Ecology and the Evolutionary Corporation; New Society Publishers: Gabriola Island, BC.

Olazabal, Nedda G. (2002) Banking the IT Paradox. McKinsey Quarterly, (1): 47 - 51.

Packard, V. (1960). "Progress through Planned Obsolescence" in V. Packard, The Waste Makers, pp $45-57$.

Price, Andrew (2008) Slow-Tech: Manifesto for an Over-wound World. New York, NY: Atlantic.

Rosen, Christine (2008) People of the Screen. The New Atlantis: Journal of Technology and Society. Fall, p. $20-32$.

Robertson, Ross (2008) A Brighter Shade of Green: Rebooting Environmentalism for the 21st Century. Wired, June 2008: 158 - 165.

Rosenstand, Nina (1994) The Moral of the Story: An Introduction to Questions of Ethics and Human Nature. Mayfield, Mountain View CA.

Rubery, Jill, Ward, Kevin, Grimshaw, Damian, Beynon, Huw

Sellen, A. and Harper, R. (2001) The Myth of the Paperless Office. The MIT Press, Boston.

Sigman, A. (2009) Technology and Community. Biologist, January, 2009.

G. Slade. (2006). Made to Break: Technology and Obsolescence in America. Cambridge. MA: Harvard University Press.

Steffen, Alex (2006) Worldchanging: A User's Guide for the 21st Century, Abrams, Inc: NY. 
Thatcher, M., and Pingry, D. (2007) "Modeling the IT Value Paradox." Communications of the ACM. 50 (8): 41 - 52.

Time Society 2005 14: 89-111

Toffler, A. (1970). Future shock. New York: Random House.

Wackernagel, M. and Rees, W. (1996) Ecological Footprint: Reducing Human Impact on the Earth; New Society Publishers: Gabriola Island, BC.

Watson, R, Marie-Claude Boudreau, Adela Chen, and Mark Huber (2008) Green IS: Building Sustainable Business Practices. The Global Text Project. http://docs.globaltext.terry.uga.edu:8095/anonymous/webdav/Information\%20Systems/G reen\%20IS.pdf.

Weizsäcker, E. U. v., Lovins, A. B., \& Lovins, L. H. (1997). Factorfour: Doubling wealth, halving resource use : the new report to the Club of Rome. London: Earthscan

Working Time, Industrial Relations and the Employment Relationship 